\title{
Specyfika opieki pielęgniarskiej nad pacjentem starszym leczonym chirurgicznie
}

\author{
The specificity of the nursing care of elderly patient treated surgically
}

\author{
Agnieszka Ulatowska1, Grażyna Bączyk², Elżbieta Włodarczyk³, \\ Małgorzata Bosacka ${ }^{4}$
}

'Katedra Pielęgniarstwa, Pracownia Praktyki Pielęgniarskiej, Wydział Nauk o Zdrowiu, Uniwersytet Medyczny im. Karola Marcinkowskiego w Poznaniu

${ }^{2}$ Katedra Pielęgniarstwa, Wydział Nauk o Zdrowiu Uniwersytet Medyczny im. Karola Marcinkowskiego w Poznaniu

${ }^{3}$ Katedra Organizacji i Zarządzania w Opiece Zdrowotnej, Wydział Nauk o Zdrowiu Uniwersytet Medyczny im. Karola Marcinkowskiego w Poznaniu ${ }^{4}$ Instytut Nauk o Zdrowiu, Państwowa Wyższa Szkoła Zawodowa im. Hipolita Cegielskiego w Gnieźnie

AUTOR DO KORESPONDENCJ:

Elżbieta Włodarczyk

ul. os. Kazimierza Wielkiego 49/4, 62-200 Gniezno e-mail: ewlodar@yahoo.com

\section{STRESZCZENIE}

Słowa kluczowe:

\section{ABSTRACT}

Key words:

\section{SPECYFIKA OPIEKI PIELEGGNARSKIEJ NAD PACJENTEM STARSZYM LECZONYM CHIRURGICZNIE}

Starzenie się organizmu ludzkiego jest procesem ciągłym i postępującym, prowadzącym do upośledzenia funkcji narządów i układów oraz zaburzającym homeostazę. Proces ten może przebiegać, co zdarza się rzadziej, bez chorób, i zwany jest wówczas starzeniem fizjologicznym. W przypadku towarzyszących stanów chorobowych pojawiają się dodatkowe zmiany narządowe, które pogarszają stan ogólny organizmu, (starzenie patologiczne). Choroby wieku podeszłego, ze względu na współwystępowanie różnych, czasami licznych jednostek chorobowych, stanowią ogromny problem dla zespołów terapeutycznych. Do najczęstszych schorzeń należą: choroby układu sercowo-naczyniowego, układu kostno-stawowego, oddechowego, pokarmowego, nerwowego oraz immunologicznego. Często mówi się o całościowym pogorszeniu zdrowia, czyli? zespole słabości? (frailty syndrome). Zespołowi towarzyszy sarkopenia, czyli utrata masy mięśniowej, niedożywienie, zmniejszenie aktywności ruchowej, zmniejszenie tolerancji wysiłku, pogorszenie funkcji poznawczych, większa wrażliwość na czynniki stresogenne. Ze względu na odrębności fizjologiczne i obecność wielu chorób pacjenci w podeszłym wieku wymagają interdyscyplinarnego leczenia, nierzadko jest to interwencja chirurgiczna, wymagająca specyficznego przygotowania do zabiegu operacyjnego, opieki po operacji i rehabilitacji. Osoby starsze są szczególnie narażone na różne powikłania pooperacyjne ze strony narządów i układów: niedotlenienie, zakażenie, hipoproteinemię, hiponatremię, hipowolemię. Prawidłowa opieka pielęgniarska powinna obejmować zarówno dokładne przygotowanie przedoperacyjne, obejmujące ocenę stanu fizycznego i psychicznego pacjenta, jak i prawidłowe postępowanie pooperacyjne i rehabilitacyjne, zmniejszające ryzyko poważnych powikłań pooperacyjnych i poprawiające dobrostan chorego.

pielęgniarstwo geriatryczne, pielęgniarstwo okołooperacyjne, chirurgia, powikłania pooperacyjne, opieka pooperacyjna

\section{WHE SPECIFICIIY OF THE NURSING CARE OF ELDERIY PATIENT TREATED SURGICALIY}

The aging of the human body is a continuous and progressive process, leading to dysfunction of organs and systems and disturbing homeostasis. Aging without additional pathology (physiological aging) occurs relatively rarely. In the case of co-morbidities (pathological aging) additional organ damage can be diagnosed, which deteriorate the condition of the elderly patient. Age-related illnesses can create complicated problems for therapeutic teams. The most common diseases include cardiovascular disease and pathology of the respiratory, digestive, nervous and immune systems. The overall deterioration of health (often named the frailty syndrome) can be accompanied by loss of muscle mass, malnutrition, decreased physical activity, decreased exercise tolerance, deterioration of the cognitive function and increased sensitivity to stressors. Due to specificity of the aged physiology and the presence of co-morbidity, elderly patients require an interdisciplinary treatment, which often requires surgery, with special need for specific preparation for the surgery, postoperative care and rehabilitation. The elderly are at particular risk for various complications after surgery from the organ systems: hypoxia, infection, hypoproteinaemia, hyponatremia, hypovolemia. Proper nursing care should include accurate preoperative preparation, including an assessment of the physical and mental status of the patient and proper postoperative management and rehabilitation, thus reducing the risk of serious postoperative complications and improve the wellbeing of the patient.

geriatric nursing, perioperative nursing, surgery, postoperative complications, postoperative care 


\section{WPROWADZENIE}

Mimo nieustannego rozwoju wszystkich dziedzin medycznych, a zwłaszcza specjalności zabiegowych, inwazyjny zabieg operacyjny u chorego w wieku podeszłym nadal może stwarzać istotne zagrożenie. Wydzielenie z chirurgii ogólnej wąskich specjalizacji zabiegowych takich jak chirurgia naczyniowa, ortopedia, neurochirurgia, chirurgia przewodu pokarmowego lub urologiczna pozwoliło w bardziej szczegółowy sposób przyjrzeć się reakcji organizmu na zastosowane znieczulenie i zabieg, jednak za każdym razem można spodziewać się objawów ze strony organizmu świadczących o zachwianiu homeostazy. Działania na rzecz zapewnienia maksymalnego bezpieczeństwa i komfortu pacjenta leczonego operacyjnie powinny obejmować zarówno czynności przygotowawcze do zabiegu, jak i ocenę ryzyka okołooperacyjnego, odpowiednie do wieku i stanu zdrowia znieczulenie oraz rehabilitację pozabiegową. Niniejsza analiza problemów i zagrożeń związanych $\mathrm{z}$ leczeniem chirurgicznym pacjentów w podeszłym wieku ma nie tylko ukazać personelowi pielęgniarskiemu, przed jak poważnym i złożonym problemem stoi, ale także podkreślić wagę funkcjonowania i współpracy pielęgniarek w ramach zespołu terapeutycznego.

Operacja (zabieg operacyjny, chirurgiczny) to inwazyjne działania na narządach lub tkankach ciała, zawsze zaburzające homeostazę organizmu. Wpływ na to maja czynniki takie jak wiek, obecność chorób przewlekłych, stan organizmu zmieniony fizjologicznie na skutek procesu starzenia się, jak i zastosowane znieczulenie oraz fizyczne działanie interwencji chirurgicznej (cięcie i koagulacja tkanek, otwarcie jam ciała, utrata krwi, wychłodzenie, zakażenie) [4].

\section{POWIKLANIA POOPERACYJNE U PACJENTÓW W PODESZZYM WIEKU}

Niezależnie od planowanych wobec pacjenta starszego działań anestezjologicznych i chirurgicznych, w okresie przedoperacyjnym, okołooperacyjnym oraz w okresie bliższym i dalszym po operacji mogą pojawiać się liczne zagrożenia. Dość często obecny jest lęk i strach, co zaburza poczucie bezpieczeństwa. Lęk jest reakcją o charakterze subiektywnym, w sferze procesów emocjonalno-motywacyjnych. Polega na niepewności, bezradności i bezsilności [5]. Somatyczne objawy lęku mogą komplikować przebieg choroby podstawowej poprzez pojawienie się objawów hipochondrii lub somatyzacji [6]. Czynnikami wywołującymi lęk może być obawa przed znieczuleniem, bólem pooperacyjnym, złą diagnozą śródoperacyjną, obecnością skomplikowanej aparatury medycznej, a w ostateczności - śmiercią. Poziom lęku może się podnosić i powodować zaburzenia adaptacyjne, co może zagrażać funkcjonowaniu organizmu podczas operacji oraz w okresie pooperacyjnym [7].

Stres wywołany urazem operacyjnym zaburza równowagę pomiędzy układami: nerwowym, hormonalnym i immunologicznym, co w połączeniu z procesem sta- rzenia może nasilać zmiany, zwłaszcza w zakresie układu odpornościowego. W okresie okołooperacyjnym i pooperacyjnym zmiany zapalne mogą mieć charakter miejscowy i ogólny. Reakcje miejscowe dotyczą zmian komórkowych i naczyniowych w miejscu urazu operacyjnego. Cechami charakterystycznymi tych reakcji są: agregacja płytek i powstawanie skrzepu, rozkurcz naczyń, zwiększenie ich przepuszczalności, zwiększenie uwalniania cytokin przez granulocyty oraz makrofagi [8]. Zakażenie miejsca operowanego (ZMO) należy do grupy zakażeń szpitalnych; pojawia się w ciągu 30 dni od dnia operacji, gdy nie były użyte materiały sztuczne np. protezy, oraz do roku w przypadku ich wykorzystania. Zakażenia rany dzielimy na: zakażenie powierzchowne (skóra i tkanka podskórna), zakażenie głębokie (powięź i mięśnie), zakażenie narządu lub jamy bezpośrednio w sąsiedztwie miejsca operowanego. Czynnikami ryzyka wpływającymi na powstanie ZMO są: niska odporność pacjenta, złe przygotowanie pacjenta do zabiegu (kąpiel, usunięcie owłosienia), brak prawidłowego przygotowania personelu, sali operacyjnej, sprzętu, materiałów, błędy aseptyczne podczas operacji, nieprawidłowa pielęgnacja rany pooperacyjnej po zabiegu, nieuzasadnione stosowanie antybiotyków o szerokim spektrum działania, co powoduje narastanie oporności [9].

W okresie pooperacyjnym zjawiskiem nasilającym zaburzenia homeostazy jest ból pooperacyjny pojawiający się, gdy przestaje działać śródoperacyjna analgezja. Jego źródłem jest uszkodzenie tkanek powierzchownych i struktur głębszych [10]. Stopień natężenia bólu odczuwanego po operacji przez chorego zależy od rozległości uszkodzenia tkanek, poziomu neurotyzmu, lęku, stopnia świadomości pacjenta oczekującego na pojawienie się bólu. Ból oddziałuje na układ wewnątrzwydzielniczy, oddechowy, sercowo-naczyniowy, narządy jamy brzusznej, metabolizm, a nieprawidłowe postępowanie przeciwbólowe w okresie pooperacyjnym niesie ze sobą ryzyko dodatkowych powikłań [11].

Okres pooperacyjny może przebiegać z zaburzeniami wydolności oddechowej. Jest to związane ze znieczuleniem ogólnym stosowanym podczas operacji. Zaburzona wówczas jest funkcja mięśni oddechowych. Powikłania oddechowe częściej dotyczą pacjentów po zabiegach torakochirurgicznych lub w obrębie jamy brzusznej. Duże znaczenie w powstawaniu powikłań ze strony układu oddechowego ma pozycja leżąca na plecach. Zmniejsza się wówczas czynnościowa pojemność, dochodzi do zamknięcia drobnych oskrzelików, przesunięcia lub zaburzeń kurczliwości przepony. Do zaburzeń oddechowych pooperacyjnych zalicza się: płytki oddech spowodowany odczuwaniem bólu w ranie pooperacyjnej, spadek stężenia hemoglobiny w wyniku dużej utraty krwi podczas zabiegu i drenażu, aspiracja treści pokarmowej do dróg oddechowych podczas intubacji, niewydolność oddechowa po podaniu opioidów, obrzęk i skurcz głośni po ekstubacji, infekcje dróg oddechowych włącznie z zapaleniem płuc przy długotrwałym unieruchomieniu [12].

Liczne zaburzenia układowe i uszkodzenia narządowe powstałe w wyniku procesu starzenia się takie jak kwasica, zaburzenia krzepnięcia krwi, zmniejszona wydolność 
nerek, wątroby, zaburzenia elektrolitowe i infekcje powodują, iż w okresie pooperacyjnym może pojawiać się hipotermia. Jest to stan obniżenia ciepłoty ciała poniżej normy, z ustrojową niewydolnością generowania wystarczającej ilości ciepła dla zachowania prawidłowej ciepłoty organizmu [13]. Bardzo dużym zagrożeniem dla starszych osób poddanych zabiegom operacyjnym jest żylna choroba zakrzepowo-zatorowa (ŻCHZ-Z). Pomimo, iż istnieją 3 główne przyczyny jej występowania (zwolnienie przepływu krwi, zmiany śródbłonka żylnego i zmiany w układzie homeostazy), to jednakże prawdopodobieństwo jej rozwoju zwiększa się wraz z wiekiem, obecnością chorób przewlekłych i wyniszczających jak nowotwory, poddaniem rozległym operacjom w obrębie jamy brzusznej, zabiegom ortopedycznym (zwłaszcza stawu biodrowego i kolanowego), unieruchomieniem w okresie okołooperacyjnym i pooperacyjnym, oraz znieczuleniem ogólnym [14].

Chorzy w wieku podeszłym z powodu zwyrodnień w układzie kostno-stawowym zażywają nadmierne ilości niesterydowych leków przeciwzapalnych, co zwiększa ryzyko krwawień z rany pooperacyjnej, rozwoju choroby wrzodowej i krwawień z przewodu pokarmowego. U osób starszych szybko postępuje hipoproteinemia oraz występuje zjawisko odwodnienia hipertonicznego. Oba stany spowodowane niedoborem wody i elektrolitów, co może wynikać z przetaczania zbyt małej ilości płynów, wynikającej z obawy przed przeciążeniem układu krążenia i przewodnieniem organizmu. Istotnym problemem pooperacyjnym są odleżyny powstające najczęściej u osób unieruchomionych, $\mathrm{z}$ nietrzymaniem moczu i stolca oraz z obniżonym stężeniem białka - głównie albumin w surowicy krwi [4].

\section{PRZEDOPERACYJNA OCENA STANU OGÓLNEGO I PRZYGOTOWANIE DO ZABIEGU CHIRURGICZNEGO PACJENTA W PODESZZYM WIEKU}

Okres przedoperacyjny jest dla każdego pacjenta istotnym obciążeniem fizycznym i psychicznym, dlatego też ważnym elementem jest przygotowanie, które rozpoczyna się rozmową pacjenta $\mathrm{z}$ lekarzami i pielęgniarkami. Celem rozmowy jest poinformowanie o konieczności operacji, wyjaśnienie nurtujących wątpliwości, udzielenie wsparcia, uspokojenie, edukacja dotycząca samoopieki i samopielęgnacji. Celem edukacji zdrowotnej jest nie tylko przekazanie wiedzy, ale również nauczenie działań sprzyjających zdrowiu. Edukacja ogranicza stres, a komunikacja jest ważnym czynnikiem relacji pielęgniarka pacjent. Według Williams kontakt z pielęgniarką jest dla pacjenta niekiedy ważniejszy niż wykonywane przez nią inne zabiegi [15]. W badaniach Kryskiewicza, Girzelskiej i wsp. wykazano, iż pacjenci chętnie przyjmują wiedzę przekazywaną przez pielęgniarki. Wiedza ta jest ukierunkowana głównie na potrzeby pacjenta [16]. Najważniejsze w przygotowaniu psychicznym jest rozpoznanie problemów oraz zapewnienie poczucia bezpieczeństwa. Pacjent w podeszłym wieku wymaga wnikliwej i komplek- sowej przedoperacyjnej oceny stanu ogólnego. Większość pacjentów, właśnie ze względu na wiek, należy traktować jako osoby z dużym obciążeniem, na co mogą się składać niedożywienie, niedobory albumin w surowicy krwi, obniżony poziom witamin i mikroelementów, zaburzenia czynności poszczególnych układów, narządów, współistnienie chorób przewlekłych, upośledzenie gojenia się ran ze względu na niedotlenienie tkankowe i hipoproteinemię. Dodatkowymi czynnikami ryzyka jest konieczność operowania w trybie pilnym. [17]. Aby ocenić ryzyko okołooperacyjne anestezjolog powinien dokonać wywiadu odnośnie przebytych i współistniejących chorób oraz określić wydolność układów i narządów. Ryzyko związane z chorobami układowymi należy rozpatrywać według trzech elementów: stanu klinicznego, wydolności czynnościowej, ryzyka związanego z procedurą chirurgiczną. Najczęściej w ocenie ryzyka okołooperacyjnego wykorzystywana jest skala ASA- anestezjologiczna skala oceny ryzyka operacyjnego (American Society of Anaesthesiology), dotycząca stanu fizycznego, opartego na ocenie wydolności układów i narządów. Za jej pomocą kwalifikuje się pacjenta do jednej z pięciu grup:

- grupa I - pacjent bez obciążeń dodatkowymi schorzeniami,

- grupa II - pacjent z niezbyt nasiloną choroba układową,

- grupa III - pacjent z ciężką chorobą układową, która ogranicza jego wydolność lub aktywność,

- grupa IV - pacjent z bardzo ciężką chorobą układową, która stanowi zagrożenie jego życia,

- grupa V - pacjent z niewydolnością wielonarządową, w stanie ciężkim, u którego z dużym prawdopodobieństwem może nastąpić zgon w ciągu 24 godzin [18].

Lęk i obniżony nastrój towarzyszą każdemu pacjentowi przyjętemu do zabiegu operacyjnego. Ponieważ somatyczne objawy lęku mogą komplikować przebieg operacji oraz rekonwalescencję pooperacyjną, należy za pomocą dostępnych narzędzi ocenić poziom lęku i depresji. Pomocna może być skala lęku i depresji HADS (Hospital Anxiety and Depression Scale), która składa się z dwóch niezależnych podskal. Pacjent samodzielnie ocenia nasilenie określonych cech w 4-stopniowej skali. Osiągnięcie w każdej podskali 0-7 punktów uznaje się za normę, 8-14 punktów oznacza zmiany umiarkowane, a od 15-21 punktów ciężkie zaburzenia emocjonalne. Badania za pomoca prezentowanej skali przeprowadzili Andruszkiewicz A i wsp. [19]. Badanie poszerzono o ocenę opieki pielęgniarskiej za pomocą skali Likerta. Wykazano, że deficyt opieki pielęgniarskiej jest skorelowany z wyższym natężeniem lęku i depresji. Do pomiaru natężenia lęku przedoperacyjnego można wykorzystać test Inwentarz Stanu i Cech Lęku (STAI/ISCL). STAI jest narzędziem przeznaczonym do badania lęku rozumianego jako przejściowy i uwarunkowany sytuacyjnie stan jednostki oraz lęku rozumianego jako względnie stała cecha osobowości. Składa się z dwóch podskal, z których jedna (X-1) służy do pomiaru lęku-stanu, a druga (X-2) - lęku-cechy. Pytania składające się na obie skale umieszczone są po obu stronach jednego arkusza testowego. Każda podskala składa się z 20 pozycji, na które badany odpowiada 
wybierając jedna z czterech skategoryzowanych odpowiedzi [20]. Badania przeprowadzone przez Bączyk G. i wsp. potwierdzają, iż w okresie przedoperacyjnym wśród pacjentów pojawia się lęk o różnym natężeniu i zależny od cech osobowości, wymagający właściwego działania psychoterapeutycznego [7]. Podstawowym elementem rozpoznania pielęgniarskiego jest ocena wydolności funkcjonalnej pacjenta przygotowywanego do zabiegu operacyjnego. Wydolność funkcjonalna to radzenie sobie z czynnościami życia codziennego. Sprawne funkcjonowanie wpływa pozytywnie na okres pooperacyjny i przyspiesza powrót do zdrowia. W jednym z badań dokonano oceny wydolności funkcjonalnej w okresie przed i pooperacyjnym. Przed zabiegiem wykorzystano w tym celu Skalę Oceny Samodzielności Funkcjonalnej (FIM, Functional Independence Measure) oraz Skalę Glasgow Wyników Końcowych (GOS, Glasgow Outcome Scale). Skala FIM jest to opublikowana w 1986 roku siedmiostopniowa skala oceniająca 18 czynności. W późniejszych latach dokonano uproszczenia skali, co doprowadziło do powstania Wskaźnika Funkcjonalnego „Repy” (WFR). Odrzucono punkty dotyczące świadomości społecznej, które należą do sfery testów psychologicznych i socjologicznych. Skala ta stała się przez to prostszym i łatwiejszym narzędziem do wykorzystania. Ocenia ona samoobsługę, kontrolę zwieraczy, mobilność i lokomocję oraz komunikację. Maksymalna ilość punktów do uzyskania to 7, co świadczy o pełnej sprawności badanego. 5 punktów oznacza umiarkowaną niezależność, gdzie pomoc potrzebna jest tylko w niektórych czynnościach. Przy uzyskaniu 3 punktów badany wymaga w większości czynności pomocy, natomiast 1 punkt oznacza całkowitą niezdolność i pełną zależność od opiekunów [21]. Wykorzystana w badaniach skala GOS najczęściej stosowana jest do oceny funkcji neurologicznych. Za pomocą jej ustala się stopnie, które odzwierciedlają stan pacjenta. I oznacza duże prawdopodobieństwo zgonu pacjenta lub zaistniały już fakt śmierci, II pacjent w stanie apalicznym, III stopień oznacza stan pacjenta ciężki z głębokimi niedowładami, przy IV stopniu stan jest dość dobry, obserwuje się niewielkie ubytki neurologiczne. Stopień V świadczy o bardzo dobrym stanie pacjenta, bez ubytków neurologicznych [21]. W ocenie występowania dolegliwości bólowych można wykorzystać Analogowo-Wzrokową Skalę Bólu (VAS, Visual Analog Scale). W ocenie bólu uwzględnia się punktację: 0 - brak bólu, 1-3 ból lekki, 4-7 ból umiarkowany, 8-10 silny ból [22]. Po operacji ocenę natężenia bólu i stresu można dokonać za pomocą skali Karnofsk'ego (KPS, Karnofsky Performance Scale). Kwestionariusz przeznaczony jest do pomiaru struktury doznań stresowych. Pozwala na obliczenie wyniku ogólnego informującego o uogólnionym poziomie stresu, a także trzech wyników odnoszących się do następujących wymiarów: napięcie emocjonalne, stres zewnętrzny oraz stres intrapsychiczny. Taka ocena pozwala dokładnie przygotować pacjenta do szybkiego reagowania na ból i samodzielnego radzenia sobie po operacji, niezależnie od jej rodzaju. Użytecznymi narzędziami w ocenie stanu pacjenta geriatrycznego mogą być skale wchodzące w skład całościowej oceny geriatrycznej (CGA - Comprehensive Geriatric Assessment). Obejmuje ona ocenę codziennego funkcjonowania, sprawności fizycznej, chorób towarzyszących, funkcji poznawczych, stanu emocjonalnego, stanu odżywienia i sytuacji socjoekonomicznej. Kompleksowość tej oceny umożliwia dokładną ocenę stanu i określenie rezerw czynnościowych i ryzyko powikłań. Dzięki dokładnej ocenie stanu pacjenta, oszacowaniu ryzyka powikłań i prognozowaniu przebiegu operacji i okresu pooperacyjnego możemy zapewnić pacjentowi maksymalne bezpieczeństwo [23].

\begin{tabular}{|c|c|}
\hline Narzędzie oceny & Zakres oceny \\
\hline \multicolumn{2}{|c|}{ Ocena stanu funkcjonalnego } \\
\hline $\begin{array}{l}\text { - Skala Katza-ADL - activities of daily } \\
\text { living } \\
\text { - Skala Lawtona IADL - instrumental } \\
\text { activities of daily living). } \\
\text { - Skala Barthel }\end{array}$ & - Codzienne funkcjonowanie \\
\hline \multicolumn{2}{|c|}{ Ocena stanu fizycznego } \\
\hline - Skala Tienetti & - ocena równowagi i chodu \\
\hline - Skala Norton & • ocena ryzyka odleżyn \\
\hline $\begin{array}{l}\text { - Skala MNA - mini nutritional } \\
\text { assesment }\end{array}$ & - ocena stanu odżywienia \\
\hline \multicolumn{2}{|c|}{ Ocena stanu umysłowego, emocjonalnego } \\
\hline $\begin{array}{l}\text { - Skala MMSE- mini mental state } \\
\text { examination }\end{array}$ & - ocena czynności poznawczych \\
\hline $\begin{array}{l}\text { - Test Hodkinsona-AMTS - abbreviated } \\
\text { mental test score }\end{array}$ & - ocena stanu emocjonalnego \\
\hline - Skala Depresji Yesagave'a, Hamiltona & \\
\hline \multicolumn{2}{|c|}{ Ocena sytuacji socjoekonomicznej } \\
\hline - Skala RAND medical suport scale & \begin{tabular}{|l} 
- ocena sytuacji socjalnej \\
i ekonomicznej oraz zapotrzebowania \\
na pomoc i wsparcie
\end{tabular} \\
\hline
\end{tabular}

Źródło: Łacko A. Specyfika leczenia chorych na nowotwory w podeszłym wieku. Medycyna Wieku Podeszłego. 2012; 2, (1): 7-11.

Przygotowanie fizyczne pacjenta jest uzależnione od jego stanu ogólnego oraz rodzaju i trybu zabiegu operacyjnego. Przewiduje ono naukę czynności zapobiegających powikłaniom pooperacyjnym. Nauka ćwiczeń oddechowych zapobiega powikłaniom ze strony układu oddechowego. Ćwiczenia ruchowe pozwalają uniknąć lub zmniejszyć ryzyko powikłań zakrzepowo-zatorowych. Rozpoczęcie ćwiczeń przed zabiegiem ułatwia rehabilitację w okresie pooperacyjnym. Świadomy pacjent będzie w mniejszym stopniu odczuwał stres i chętniej współpracował z personelem medycznym. W przypadku operacji na przewodzie pokarmowym wskazane jest opróżnienie jego światła. Sposób przygotowania przewodu pokarmowego zależy od przyjętego standardu w oddziale. Przygotowanie fizyczne obejmuje również zadbanie o higienę całego ciała, a zwłaszcza pola operacyjnego. Usuwanie owłosienia powinno odbywać się w dzień zabiegu za pomocą golarki chirurgicznej z wymiennymi końcówkami. Powszechną metodą zapobieganie zakażeniom okołooperacyjnym jest profilaktyczne stosowanie antybiotyków (doustnie lub dożylnie). 


\section{POOPERACYJNA OPIEKA PIELĘGNIARSKA NAD PACJENTEM W PODESZKYM WIEKU}

Po zakończonym zabiegu operacyjnym pacjent zostaje umieszczony w sali wybudzeń w sąsiedztwie bloku operacyjnego. Tam pielęgniarka, przejmując pacjenta, sprawdza jego dane osobowe, przyjmuje dokumentację medyczną wraz ze zleceniami lekarskimi. Podejmując opiekę pooperacyjną nad starszym pacjentem działania powinny być skupione na monitorowaniu stanu ogólnego i rozpoznawaniu powikłań. W badaniach Cybulskiej V i wsp. przeprowadzonych wśród 50 pielęgniarek z oddziałów zabiegowych określono działania pielęgniarskie wobec pacjenta starszego leczonego chirurgicznie. W tym celu posłużono się kwestionariuszem ankiety, w której pytano personel o opinie na temat najczęstszych przyczyn zagrożeń zdrowotnych pojawiających się u pacjentów geriatrycznych w planowaniu i realizacji opieki pooperacyjnej. Stwierdzono, że $54 \%$ badanych przede wszystkim rozpoznaje zaburzenia układu krążenia i oddechowego, 50\% obserwuje pacjenta pod kątem wstrząsu, krwotoku. W opinii $48 \%$ ankietowanych prowadzona jest walka z bólem i uporczywymi wymiotami, $20 \%$ badanych działa w celu zapewnienia higieny skóry, jamy ustnej, poprawiając tym samym komfort fizyczny i psychiczny [24].

Podstawowym działaniem wobec pacjenta starszego po zabiegu operacyjnym jest obserwacja. Uwzględnia się tu wiele działań, a po zaobserwowaniu niepokojących symptomów należy natychmiast rozpocząć działania przywracające stabilność organizmu. Pierwszą czynnością jest kontrola stanu świadomości, oceniająca stan wybudzenia, kontakt $\mathrm{z}$ chorym i jego reakcje na bodźce zewnętrzne po stosowanym znieczuleniu ogólnym. Pomiar ciśnienia i tętna konieczny jest w celu wczesnego rozpoznania groźnych powikłań, na przykład krwawienia. Przy zastosowaniu znieczulenia podpajęczynówkowego może dojść do spadku ciśnienia tętniczego, bowiem blokada układu współczulnego i rozkurcz naczyń prowadzi do hipowolemii i spadku powrotu żylnego, co wtórnie może stanowić zagrożenie dla pacjenta $\mathrm{z}$ obniżoną rezerwą kardiologiczną [25]. Zmiany jego wartości zależą również od wysokości znieczulenia podpajęczynówkowego i możliwości adaptacyjnych pacjenta. Pomiaru ciśnienia i tętna dokonuje się w dwóch pierwszych godzinach co 15-30 minut, a następnie co 1-3 godziny, w zależności od stanu pacjenta. Jednocześnie ocenia się częstość i głębokość oddechów. Zmiany w tempie i charakterze oddechu mogą świadczyć o pojawieniu się bólu, zaburzeń oddechowo-krążeniowych lub gorączki, która w okresie pooperacyjnym jest niepokojącym objawem. Kontrola temperatury ciała powinna odbywać się co najmniej dwa razy dziennie, a jej istotne podwyższenie może świadczyć o pojawieniu się zakażenia. Najczęstszym zakażeniem okresu pooperacyjnego jest zakażenie rany. Innym źródłem zakażeń mogą być cewniki i dreny, ich nieprawidłowa pielęgnacja, nieprzestrzeganie zasad aseptyki. Badania przeprowadzone przez Bartoszewicz M i wsp. wykazały, że prawidłowe zastosowanie środka odkażającego Octaniseptu ${ }^{\circledR}$ na patogeny obecne w cewniku i na niciach chirurgicznych powoduje usunięcie szczepów bakterii w ciągu jednej minuty od zastosowania [26]. Poza możliwością wystąpienia gorączki u pacjenta po zabiegu może wystąpić hipotermia. Udowadniają to Harzowska J i wsp. w swoim badaniu. Grupę badawczą stanowiło 112 pacjentów, u których mierzono temperaturę ciała przed i po zabiegu. U 55 chorych stwierdzono hipotermię pooperacyjną [13]. Analiza badania wskazuje na poszczególne czynniki mogące wpływać na obniżenie temperatury ciała pacjenta po zabiegu operacyjnym.

Szczególną uwagę należy zwrócić na rodzaj znieczulenia zastosowanego u pacjenta starszego. Wskutek rozszerzenia naczyń obwodowych obniżenie ciepłoty ośrodkowej występuje jeszcze w czasie operacji. Hipotermia często występuje u pacjentów znieczulanych przewodowo. Hamowanie reakcji termoregulacyjnych jest proporcjonalne do rozległości blokady. Im dłużej trwa zabieg, tym większe prawdopodobieństwo wystąpienia hipotermii. Dalsza analiza wykazała, iż im więcej nieogrzanych płynów infuzyjnych się przetacza, tym niższa jest temperatura ciała, dlatego też niezbędne jest ich ogrzewanie przed podaniem. Wykazano również, że czynniki takie jak temperatura w sali operacyjnej czy wcześniejsze ogrzewanie pacjenta kocami nie mają istotnego znaczenia do utrzymania jego prawidłowej ciepłoty ciała [25].

Kolejnym parametrem podlegającym obserwacji jest diureza. Częstym sposobem na jej kontrolę jest założenie do pęcherza moczowego cewnika Foley’a. Pozwala to dokładnie ocenić objętość i jakość (kolor, domieszka krwi) diurezy pacjenta. Podejmując decyzję o jego założeniu pamiętać należy o problemach i powikłaniach charakterystycznych dla pacjentów w starszym wieku np. przerost gruczołu krokowego u mężczyzn, większa podatność na zakażenia dróg moczowych z powodu niskiej odporności pacjenta. Należy więc rozważyć metody mniej inwazyjne, jak dobowa zbiórka moczu, wymagająca ciągłego nadzoru pacjenta.

Obserwacji podlega również rana pooperacyjna. Opatrunek należy regularnie oceniać pod kątem krwawienia, pojawiania się wydzieliny, szczelności szwów. W przypadku wyprowadzonych drenów kontrolujemy ilość i rodzaj wydzieliny odprowadzanej do butelek Redona. Zmiany opatrunku wykonuje się według potrzeby. Opatrunek musi być sterylny, suchy i dokładnie zabezpieczać ranę. Szczególnej obserwacji podlegają wszystkie dreny i cewniki [26]. Sonda żołądkowa musi być prawidłowo umieszczona w żołądku, drożna i przymocowana. Założony zgłębnik pozwala obserwować ilość i rodzaj treści żołądkowej, która po zabiegach na przewodzie pokarmowym jest kolejnym ważnym elementem pielęgniarskiej obserwacji.

Kaniula dożylna może być przyczyną niebezpiecznej dla pacjenta infekcji ogólnoustrojowej. Należy więc obserwować miejsce wkłucia pod kątem objawów stanu zapalnego (obrzęk, zaczerwienienie, ból, miejscowe podwyższenie ciepłoty).

Jednym z istotniejszych elementów opieki pooperacyjnej jest walka z bólem pooperacyjnym. Pierwszym krokiem jest monitorowanie bólu. W celu określenia 
intensywności cierpienia pacjenta ważna jest obiektywna obserwacja objawów fizycznych oraz określenie subiektywnych objawów lęku i strachu. Ochsner i wsp. udowodnili w swoim badaniu, iż istnieje powiązanie między strachem, lekiem a bólem. Do przeprowadzenia badania wykorzystali test FPQ III (Fear of Pain Questionnnaire) - służy on do określenia strachu związanego z różnymi zdarzeniami fizycznymi indukującymi ból i indeksu ASI (Anxiety Sensititive Index) - używany jest do określenia wrażliwości lękowej pojawiającej się w kontekście objawów somatycznych takich jak odczuwalne bicie serca lub poczucie zdenerwowania [27]. Inne badania przeprowadzone w Wielkiej Brytanii i Stanach Zjednoczonych udowodniły korelację między subiektywnymi ocenami pacjentów cierpiących $\mathrm{z}$ powodu bólu a oceną jego nasilenia przez personel medyczny. Uznano, iż koniecznym działaniem jest dokonywanie oceny natężenia bólu za pomocą obiektywnych narzędzi. Dzięki nim ból staje się mierzalnym parametrem [28]. Do metod obrazowania stanów bólowych pacjenta należą przedstawione poniżej skale (Tab. 2) [29].

Dzięki dokładnej ocenie bólu pooperacyjnego można zaplanować skuteczną terapię przeciwbólową. U osób w podeszłym wieku ważne jest, aby stosowane leki analgetyczne znosiły ból, a jednocześnie nie zaburzały funkcjonowania obciążonych wiekiem układów i narządów. Ponadto ważne jest, aby nie zaburzały działania leków podawanych pacjentowi z powodu wielu chorób przewlekłych.

Postępowanie wobec pacjenta geriatrycznego po zabiegu operacyjnym to nie tylko monitorowanie stanu ogólnego i bólu pooperacyjnego, ale również osiąganie poczucia bezpieczeństwa przez chorego. Należy zapewnić przyjazną atmosferę, dbać o spokój, ciszę, czystą bieliznę pościelową i osobistą, wygodne ułożenie w łóżku, reagowanie na skargi i prośby pacjenta, pomoc przy zabiegach higienicznych. Skupiając się na całościowej opiece należy zaplanować działania usprawniające pacjenta. Mają one na celu przygotowanie chorego do samoopieki i samopielęgnacji. W pierwszych dniach po zabiegu należy wdrożyć rehabilitację fizyczną, psychiczną i społeczną. Ma ona znaczenie zapobiegające powikłaniom pooperacyjnym. Szczególną uwagę zwraca się na profilaktykę chorób układu oddechowego i układu krążenia. Ćwiczenia muszą być dostosowane do możliwości pacjenta, a ich zakres rozszerzany według zlecenia lekarskiego. Początkowo pacjent jest sadzany na łóżku, wykonuje gimnastykę oddechową, ma wykonywane oklepywanie klatki piersiowej. W ramach profilaktyki zakrzepowej należy pacjenta pionizować. Wstawanie z łóżka i chodzenie musi odbywać się z asekuracją pielęgniarki. Pacjent starszy należy do grupy chorych z podwyższonym ryzykiem upadków ze względu na zaburzenia równowagi spowodowane nie tylko zabiegiem operacyjnym, ale również niedotlenieniem mózgu, osłabieniem aparaty ruchu, zaburzeniami w funkcjonowaniu błędnika [24]. Rehabilitacja ruchowa zabezpiecza również chorego przed wystąpieniem odleżyn. Z badań Cybulskiej i wsp. przeprowadzonych wśród pielęgniarek z oddziałów zabiegowych wynika, że u pacjentów w podeszłym wieku częściej dochodzi do powikłań związanych z późnym uruchamianiem ich po zabiegu operacyjnym [22].

Podczas pobytu w szpitalu pacjent powinien być on nie tylko leczony, pielęgnowany i rehabilitowany, ale również edukowany. Proces edukacji musi dotyczyć również rodziny, gdyż pacjent starszy ze względu na zaburzenia pamięci, a niekiedy i zaburzenia procesów poznawczych nie jest wstanie przyswoić i wdrożyć pożądanego sposobu postępowania. Celem edukacji jest nie tylko udzielanie informacji, ale przekonanie pacjenta do korzystania $\mathrm{z}$ nich w swoich działaniach prozdrowotnych. Pacjent wychodząc ze szpitala, wraz z rodziną powinien być wyposażony w wiedzę i umiejętności z zakresu samokontroli, samo-

Tab. 2. Skale obrazowania bólu

\begin{tabular}{|c|c|c|}
\hline $\begin{array}{l}\text { Rodzaj skali do oceny bólu } \\
\text { pooperacyjnego }\end{array}$ & Instrukcja korzystania ze skali & Interpretacja uzyskanych wyników- ocena bólu \\
\hline $\begin{array}{l}\text { Słowna skala opisowa } \\
\text { (Verbal Discriptor Scale -VDS) }\end{array}$ & Użycie cyfr 0-3 lub liter A-D & $\begin{array}{l}\text { Skala polega na stopniowaniu, im mniejsza cyfra lub początkowa litera } \\
\text { alfabetu tym ból słabszy, im większa cyfra lub dalsza litera alfabetu tym } \\
\text { ból silniejszy. } \\
\text { - Uzyskanie } 0 \text { lub A - brak bólu } \\
\text { - Uzyskanie } 3 \text { lub D - silny ból }\end{array}$ \\
\hline $\begin{array}{l}\text { Wzrokowa skala analogowa } \\
\text { (Visual Analogue Scale - VAS) }\end{array}$ & $\begin{array}{l}\text { Stosowanie } 10 \mathrm{~cm} \text { linii prostej z naniesioną podziałką } \\
\text { od } 0 \text { do } 10\end{array}$ & \begin{tabular}{|l} 
Naniesienie punktu na cyfrze 0 oznacz brak bólu, punkt umieszzzony \\
na cyfrze 10 to ból nie do zniesienia. Ocena natężenia bólu polega na \\
nanoszeniu punktów od 0-10, im większa cyfra, tym ból silniejszy.
\end{tabular} \\
\hline $\begin{array}{l}\text { Skala numeryczna } \\
\text { (Numerical Rating Scale - NRS) }\end{array}$ & $\begin{array}{l}\text { Stosowanie punktacji od } 0 \text { do } 100, \text { maksymalną } \\
\text { wartością mogą być cyfry: } 5,20,50,100\end{array}$ & $\begin{array}{l}\text { Określenie przez pacjenta cyfry ocenia natężenie bólu. } 0 \text { oznacza brak } \\
\text { bólu, im większa cyfra tym ból silniejszy, podanie najwyższej wartości } \\
\text { cyfry zastosowanej w skali oznacza ból silny, nie do zniesienia }\end{array}$ \\
\hline Prince Henry Pain Scale & $\begin{array}{l}\text { Stosowanie punktacji od } 0 \text { do } 4 \text { przy zastosowaniu } \\
\text { głębokiego wdechui kaszlu. Pacjent zostaje } \\
\text { poproszony o wykonanie głębokiego wdechu, jeśli nie } \\
\text { odczuwa bólu wówczas prosimy o odkasłanie }\end{array}$ & $\begin{array}{l}0 \text { - brak bólu w czasie kaszlu, } \\
1 \text { - ból w czasie kaszlu, ale nie w czasie głębokiego oddychania } \\
2 \text { - ból jedynie w czasie głębokiego oddychania } \\
3 \text { - lekki ból w spoczynku } \\
4 \text { - ciężki ból w spoczynku } \\
\end{array}$ \\
\hline $\begin{array}{l}\text { Metoda twarzy bólu } \\
\text { (The faces of Pain Scale - FPS) }\end{array}$ & $\begin{array}{l}\text { Wykorzystanie rysunków twarzy od uśmiechu poprzez } \\
\text { grymas aż do płaczu }\end{array}$ & $\begin{array}{l}\text { Wskazanie przez pacjenta uśmiechniętej twarzy oznacza brak bólu. } \\
\text { Kolejne twarze zmieniają swoją ekspresję w miarę narastającego bólu. } \\
\text { Twarz płacząca oznacz bardzo silny ból } \\
\end{array}$ \\
\hline Kwestionariusz bólu McGill-a & $\begin{array}{l}\text { Zastosowanie kart z dwoma rzutami ludzkiego } \\
\text { ciała (przód i tył), oraz skali cyfrowej do określenia } \\
\text { natężenia bólu }\end{array}$ & $\begin{array}{l}\text { Pacjent na rysunkach zaznacza miejsce odczuwanego bólu, a za } \\
\text { pomocą cyfr określa natężenie bólu. Im wyższa wartość cyfry, tym bol } \\
\text { silniejszy }\end{array}$ \\
\hline
\end{tabular}

Źródło: Mędrzycka-Dąbrowska W, Ogrodniczuk M. Udział pielęgniarki w procesie monitorowania i terapii bólu pooperacyjnego. Anestezjologia i Ratownictwo 2014;8:200-205. 
opieki i samopielęgnacji. Jak wynika z badań Girzelskiej i wsp., większość pacjentów łączy swój trybu życia z obecnością choroby, jednakże w momencie przyjęcia w oddział szpitalny pacjenci nie posiadają wiedzy z zakresu zachowań prozdrowotnych. Stwierdzono również, że edukacja pielęgniarek prowadzona jest poprawnie, a informacje udzielane pacjentom są wystarczające i przekazane przystępnie [30].

\section{PODSUMOWANIE}

Wraz z wiekiem choroby i ich leczenie stają się bardziej złożone i wieloaspektowe. Reakcja ogólnoustrojowa na chorobę i operację staje się wolniejsza i mniej gwałtowna. Współistniejące choroby oraz liczne zagrożenia wynikające z zabiegu operacyjnego i podeszłego wieku pacjenta narzucają konieczność prowadzenia dokładnej przed i pooperacyjnej obserwacji pacjenta, a zapewnienie profesjonalnej opieki pielęgniarskiej polega na przewidywaniu i uwzględnieniu jego realnych potrzeb. Znajomość złożoności procesu starzenia się i wynikających z niego problemów jest nieodzownym warunkiem holistycznej opieki nad pacjentem geriatrycznym. Opieka przed i pooperacyjna musi być prowadzona na podstawie procesu pielęgnowania. Kompleksowa ocena pacjenta, planowane działania i podejmowane czynności muszą wynikać z diagnozy pielęgniarskiej. Największym problemem podczas sprawowania opieki pielęgniarskiej nad pacjentem geriatrycznym leczonym chirurgicznie jest pojawiająca się niesprawność fizyczna, psychiczna i społeczna wynikająca $\mathrm{z}$ wieku podeszłego. Nie wolno więc stosować postępowania rutynowego. Każdy pacjent musi być indywidualnie przygotowany do operacji, zgodnie $\mathrm{z}$ dostosowanym do własnego przypadku procesem pielęgnowania i rehabilitacji. Bardzo ważne jest udzielenie wsparcia informacyjnego, emocjonalnego, doradztwo i edukacja zdrowotna oraz pełna, wzajemna współpraca zespołu terapeutycznego, pacjenta i rodziny.

\section{PIŚMIENNICTWO}

1. Wieczorowska-Tobis K. Zmiany narządowe w procesie starzenia. Polskie Archiwum Medycyny Wewnętrznej. 2008; 118 (Suppl).

2. Grabowski K, Markocka-Mączka K, Taboła R. Czy istnieją różnice w postępowaniu z pacjentem chirurgicznym w starszym wieku? Psychogeriatria Polska. 2013;10(3):109-114

3. Chow WB, Rosenthal R, Merkow RP et al. Optimal preoperative assessment of the geriatric surgical patient: A best practices guideline from The American College of Surgeons National Surgical Quality Improvement Program and the American Geriatis Society. J Am Coll Surg. 2012; 215(4): 453-466.

4. Bielecki K, Kaniewska K. Wiek jako czynnik ryzyka leczenia chirurgicznego chorych w podeszłym wieku. Postępy Nauk Medycznych. 2008; 11: 708-711.

5. Horney K. Neurotyczna osobowość naszych czasów. PWN; Warszawa, 1982.

6. Andruszkiewicz A, Idczak H, Kocięcka A i wsp. Subiektywna ocena opieki pielęgniarskiej a poziom lęku i depresji u pacjentów chirurgicznych. Pielęgniarstwo Polskie. 2005; 1(19): 46-48.
7. Bączyk G, Poniedziałek B, Skokowska B. Poziom lęku przedoperacyjnego u chorych leczonych chirurgicznie. Pielęgniarstwo Polskie. 2005; 1(19):42-45

8. Lisowska B, Ząbek J, Kontny E i wsp. Wpływ stresu operacyjnego na wybrane parametry immunologiczne i biochemiczne u pacjentów z reumatoidalnym zapaleniem stawów. Reumatologia. 2007;45,6:331-337.

9. Montewka M, Skrzek A, Plewik D i wsp. Zakażenia miejsca operowanego charakterystyka czynników ryzyka, endogennych źródeł zakażenia i metody zapobiegania. Post. Mikrobiol. 2012; 51, 3: 227-235.

10. Juszczak K. Rola pielęgniarki w zwalczaniu bólu pooperacyjnego. Pielęgniarstwo Chirurgiczne i Angiologiczne. 2009; 4:131-134.

11. Piotrowski D, Gaszyński W, Kaszyński Z. Skuteczne zwalczanie bólu pooperacyjnego i jego implikacje kliniczne. Polski Przegląd Chirurgiczny. 1999; 7:725-732.

12. Mazurek M. Metody wspomaganie wydolności oddechowej w okresie okołooperacyjnym. Pielęgniarstwo Chirurgiczne i Angiologiczne. 2009; 2:47-52.

13. Harzowska J, Kózka M. Czynniki wpływające na wystąpienie hipotermii w okresie pooperacyjnym. Pielęgniarstwo Chirurgiczne i Angiologiczne. 2011;2:47-53.

14. Urbanek T, Ziaja D. Profilaktyka żylnej choroby zakrzepowo-zatorowej w chirurgii urologicznej. Przegląd Urologiczny. 2008; 2(48).

15. Williams SA. Quality and care, patient's peceptions. J. Nurs. Care Qual.1998;12(6):1825.

16. Kryskiewicz AD. Zasób informacji pacjentów hospitalizowanych jako wyznacznik opieki pielęgniarskiej. Trzeci Kongres Pielęgniarek Polskich-referaty kongresowe. PTP. Busko Zdrój 1998; 49-53.

17. Forrest JB, et al. Multicenter study of general anesthesia III. Predictors of severe perioperative adverse outcomes. Anesthesiology. 1992;76: 3-15.

18. Michalik E. Przedoperacyjna ocena i postępowanie okołooperacyjne u chorych w wieku podeszłym. Postępy Nauk Medycznych. 2008; 11: 712-721.

19. Andruszkiewicz A, Idczak H, Kocięcka A i wsp. Subiektywna ocena opieki pielęgniarskiej a poziom lęku i depresji u pacjentów chirurgicznych. Pielęgniarstwo Polskie. 2005; 1(19): 46-48.

20. Sosnowski T, Wrzesiński K. Polska adaptacja Inwentarza STAI do badania stanu i cech lęku. Przegląd Psychologiczny. 1983; 2: 393-412.

21. Opara J, Chromy M, Szeliga-Cetnarska i wsp. "Repty” jako propozycja do ogólnopolskiego zastosowania w celu oceny stopnia uszkodzenia i stanu funkcjonalnego u chorych z niedowładem połowiczym. Postępy Rehab. 1997; XI, 1: 83-88

22. Ślusarz R, Kubiatowska M, Szrajda J i wsp. Ocena wydolności funkcjonalnej pacjentów przed zabiegiem neurochirurgicznym i po jego wykonaniu. Problemy Pielęgniarstwa. 2010; 18(4):379-383.

23. Łacko A. Specyfika leczenia chorych na nowotwory w podeszłym wieku. Medycyna Wieku Podeszłego. 2012; 2, 1, 7-11.

24. Cybulska V, Koźlak V. Specyfika i odrębności sprawowania przed i pooperacyjnej opieki pielęgniarskiej nad pacjentem geriatrycznym. Problemy Pielęgniarstwa. 2009; 17 (3):184-189.

25. Lisowska B. Odmienności znieczulenia regionalnego u pacjentów w podeszłym wieku. Geriatria. 2008.s.329-333.

26. Bartoszewicz M, Rygiel A. Biofilm jako podstawowy mechanizm zakażenia miejsca operowanego - metody prewencji w leczeniu miejscowym. Chirurgia Polska. 2006;8,3:171-178.

27. Ochsner KN, Ludlow DH, Knierin K, et al. Neural correlates of indyvidual differences in pain-related fear and anxiety. Pain. 2006; 69-77.

28. De Rond M, De Wit R, Van Dam F. The implementation of a pain monitoring programme for nurses in daily clinical practice; results of a follow up study in five hospitals. Jurnal Advanc Nurs. 2001;29: 590-598.

29. Mędrzycka-Dąbrowska W, Ogrodniczuk M. Udział pielęgniarki w procesie monitorowania i terapii bólu pooperacyjnego. Anestezjologia i Ratownictwo. 2014;8:200-205.

30. Girzelska J, Kościołek A, Mianowana V i wsp. Funkcja edukacyjna pielęgniarki wobec pacjentów przebywających na oddziale chirurgicznym. Problemy Pielęgniarstwa. 2010; 18(4):420-428

Praca przyjęta do druku: 30.07 .2015

Praca zaakceptowana do druku: 07.09.2015 